\title{
Strategi Pengembangan Sistem Informasi Pelaporan Kemajuan Kerja Di Masa Pandemi Covid 19
}

\author{
Azhar Maolana ${ }^{1}$, Cecep Kurnia Sastradipraja ${ }^{2}$ \\ 1,2 Politeknik Piksi Ganesha; Jl. Jendral Gatot Subroto No. 301Bandung, Jawa Barat \\ Email: azharmaolana14@gmail.com ${ }^{1}$, cecep.kurnia.sastradipraja@ piksi.ac.id ${ }^{2 *}$
}

\begin{abstract}
Abstrak
Penelitian ini bertujuan untuk mengembangkan sistem informasi laporan kemajuan pekerjaan selama masa pandemi Covid19 di PT. Parahyangan Teknika Persada Bandung. Hal ini didasarkan pada temuan dalam penelitian yang dilakukan bahwa proses pengolahan data untuk pelaporan kemajuan data pekerjaan saat ini masih manual dan membutuhkan interaksi langsung antar pegawai sehingga selain sering terjadi miss komunikasi, data tercecer, penumpukan laporan juga rentan terhadap penyebaran covid19. Dalam penelitian ini pengumpulan data dilakukan dengan menggunakan teknik studi kepustakaan, observasi, dan wawancara. Untuk pengembangan perangkat lunak menggunakan metode prototype. Perangkat lunak ini berorientasi pada lingkungan web menggunakan bahasa pemrograman PHP dan database MySQL. Untuk pengujian sistem dilakukan dengan menggunakan pengujian BlackBox, dan pengujian kegunaan dilakukan dengan menyebarkan kuesioner kepada stakeholders perusahaan, kemudian hasil kuesioner tersebut diolah dan pengukuran data dilakukan dengan menggunakan skala likert. Berdasarkan hasil penelitian bahwa fungsionalitas aplikasi yang dibangun bebas dari kesalahan dan stakeholder dominan menyatakan sangat puas dengan persentase 96,64\%, hal ini berarti aplikasi telah memenuhi kebutuhan pengguna dan dapat diterapkan di PT. Parahyangan Teknika Persada Bandung.
\end{abstract}

Kata Kunci: sistem informasi, laporan kemajuan, covid 19

\begin{abstract}
This study aims to develop an information system for work progress reports during the Covid19 pandemic at PT. Parahyangan Teknika Persada Bandung. This is based on the findings in the research conducted that the data processing process for reporting the progress of work data is currently still manual and requires direct interaction between employees so that in addition to frequent misscommunication, scattered data, report buildup is also vulnerable to the spread of covid19. In this study, data collection was carried out using literature study, observation, and interview techniques. For software development using the prototype method. This software is oriented to the web environment using the PHP programming language and MySQL database. For system testing, it is done using BlackBox testing, and usability testing is done by distributing questionnaires to company stakeholders, then the results of the questionnaire are processed and data measurement is carried out using a Likert scale. Based on the results of the study that the functionality of the application that was built was free from errors and the dominant stakeholders stated that they were very satisfied with the percentage of 96.64\%, this means that the application has met the needs of users and can be applied at PT. Parahyangan Teknika Persada Bandung.
\end{abstract}

Keywords: systeminformation, progress report, covid 19 


\section{PENDAHULUAN}

Pesatnya perkembangan teknologi informasi seperti penyimpanan, pengolahan dan pengelolaan data[1]telah mencapai tingkat kebutuhan sehingga semua institusi termasuk anggota pelaksana proyek termotivasi untuk maju, memanfaatkannya, dan memitigasi atau menghilangkan ancaman identitas [2], terutama pada masa pandemi Covid19 saat ini. Sehingga menjadi tantangan untuk melakukan penyesuaian dalam perencanaan dan pelaksanaan setiap tahapan proyek melalui Adaptive Management Plan (AMP) [3]. Sistem Informasi Proyek adalah cara untuk membuka, menempatkan, dan memantau semua sumber daya yang terlibat dalam suatu proyek untuk mencapai tujuan yang telah ditentukan. Proyek yang berhasil didefinisikan sebagai proyek yang memenuhi tanggal target, memenuhi biaya target, memenuhi tingkat kinerja yang diinginkan, menggunakan sumber daya secara efektif dan efisien[4, p. 1]. PT. Parahyanga Teknika Persada didirikan pada awal tahun 2017, sebagai perusahaan manufaktur di Bandung, Jawa Barat - Indonesia.

Sebagai Perusahaan Manufaktur baik di bidang Mekanikal maupun Elektrikal, lembaga ini berupaya memenuhi kebutuhan bidang Medis, seperti Sistem Terpadu Ruang Operasi, IPAL, Instalasi Gas Medis, dan Instalasi Listrik dan Elektronika. Untuk tetap menjadi perusahaan manufaktur yang andal dan terpercaya, lembaga ini berkomitmen untuk melakukan penelitian dan pengembangan di bidang pendidikan, ilmu pengetahuan, dan teknologi. Dengan tujuan untuk dapat memajukan Sumber Daya Manusia khususnya bidang engineering di Indonesia. Sebagai perusahaan yang aktif dalam melaksanakan proyek-proyek, maka diperlukan pembaharuan strategi pengembangan teknologi dan informasi dalam mengelola proyek-proyeknya. Pasalnya, sistem informasi proyek masih dikerjakan secara semi manual dengan dampak seringnya miss communication dan tingginya intensitas interaksi satu sama lain, membuat ancaman penyebaran dari penyakit Covid 19 menjadi rentan [5]. Bagaimana mengelola semua proyek secara efisien menjadi tanggung jawab semua pihak yang terlibat dalam pelaksanaan proyek [6].

Pengawasan merupakan salah satu fungsi dalam pengelolaan suatu organisasi, yang berarti suatu proses kegiatan pemantauan dan evaluasi[7]. Masalah akan muncul jika ada pelaksanaan lebih dari satu proyek pada waktu yang sama. Manajemen sumber daya sangat penting, terutama jika perusahaan memiliki sumber daya yang terbatas. Misalnya, suatu perusahaan harus membagi semua tugas dalam pelaksanaan proyek untuk sejumlah sumber daya manusia yang terbatas. Hal ini akan menimbulkan peran ganda bagi setiap sumber daya manusia. Seorang karyawan dapat terlibat dalam beberapa proyek sekaligus dengan judul yang berbeda-beda. Masalah yang sering muncul adalah pengawasan. Dengan menggunakan sistem informasi proyek manual, kegiatan pemantauan menghabiskan banyak sumber daya waktu. Penanggung jawab proyek harus mengamati secara langsung situasi dan kondisi di lapangan untuk memantau kemajuan pelaksanaan proyek[8]. Dengan adanya sistem informasi pelaksanaan proyek yang terkomputerisasi, sumber daya manusia yang terlibat dapat dikoordinasikan tanpa perlu pertemuan tatap muka. Manajer Proyek dapat mengetahui bagaimana proyek berlangsung dan siapa yang bertanggung jawab untuk setiap proyek.

\section{METODE PENELITIAN}

\section{A. Metode}

Dalam pemodelan sistem, instrumen yang digunakan adalah prosedural yaitu dengan mendeskripsikan aliran data dengan alat bantu flowmap, diagram konteks, DFD. Pengembangan sistem menggunakan metode prototype. Pada tahapan implementasinya menggunakan bahasa pemrograman PHP dan MySQL sebagai databasenya. Pada pengujian sistem fungsional perangkat lunak menggunakan BlackBoxdan metode evaluasi user experience menggunakan pengujian kegunaan (usability testing). Untuk mendukung kegiatan penelitian ini diperlukan suatu kerangka kerja yang dilakukan berdasarkan tahapan-tahapan yang terstruktur dan sistematis. Adapun deskripsi dari framework yang dibuat seperti pada gambar 1 dibawah ini. 


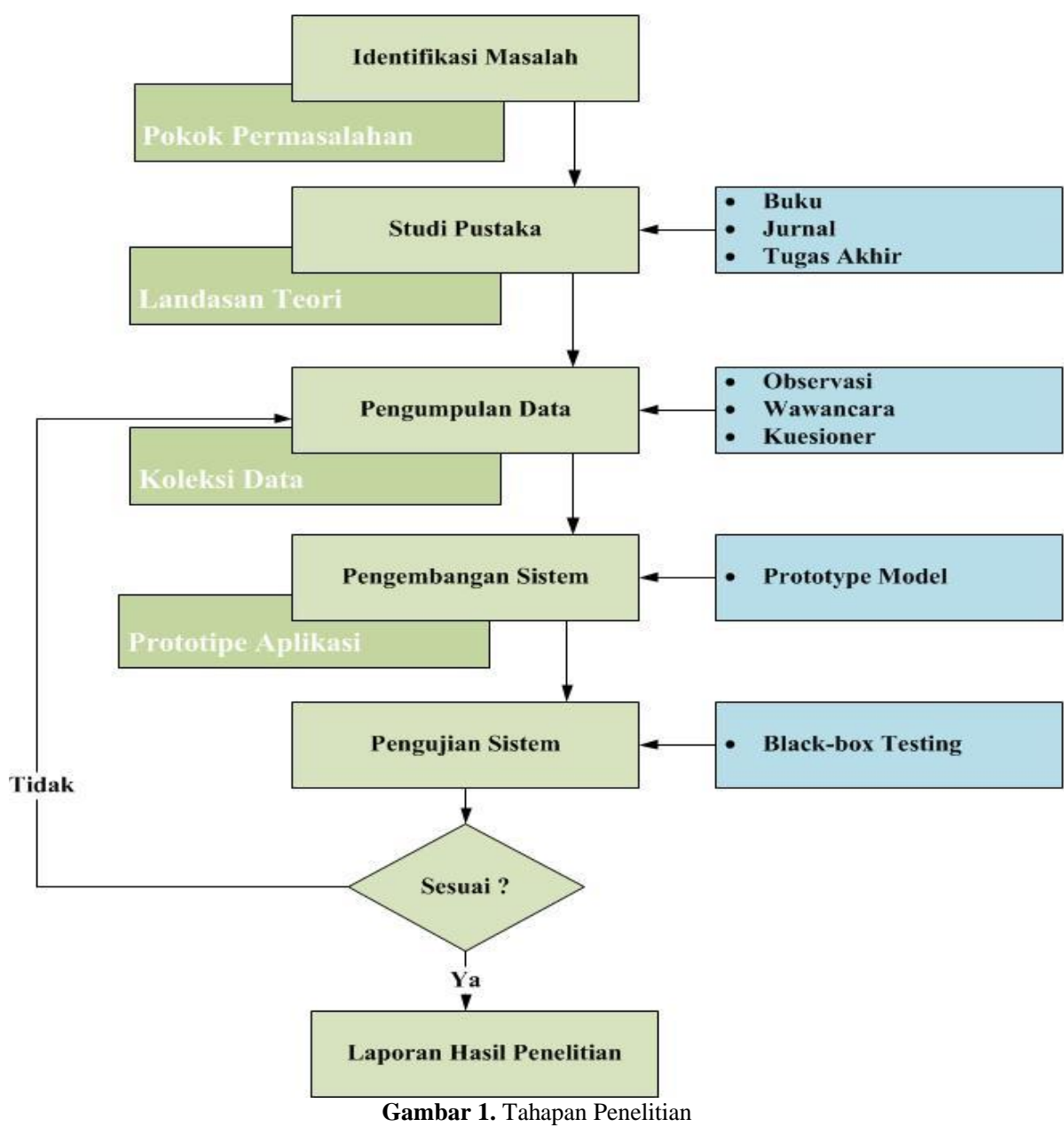

\section{B. Analisis Sistem (Exixting)}

Pada konteks ini dilakukan analisis prosedur sistem laporan kemajuan pekerjaan yang sedang berjalan dalam rangka untuk mengetahui alur data, informasi, dan mekanisme yang ada di perusahaan PT. Parahyangan Teknika Persada saat ini, sebagaimana uraian berikut ini.

a. Analis mengirimkan laporan kepada staf HPP (Harga Pokok Produksi).

b. Laporan yang diterima oleh staf HPP segera dikirim ke atasan dan diperiksa.

c. Setelah dilakukan pengecekan laporan dari staf HPP oleh supervisor akan dikirimkan kepada direktur perusahaan.

d. Setelah mengecek laporan yang diterima dari supervisor, akan dikirim kembali ke HPP untuk diverifikasi dan diserahkan ke marketing administrator

e. Setelah terdaftar dengan administrator pemasaran, laporan akan disimpan dalam repositori untuk laporan lainnya.

Berikut ini merupakan gambaran visual sistem yang ada dalam bentuk flow map dan tabel evaluasinya.

1. Flowmap sistem informasi yang ada di PT. Parahyangan Persada Teknika 
JURSISTEKNI (Jurnal Sistem Informasi dan Teknologi Informasi) Vol 3, No.3, September 2021: Hal 9- 18 ISSN. P: 2715-1875, E: 2715-1883

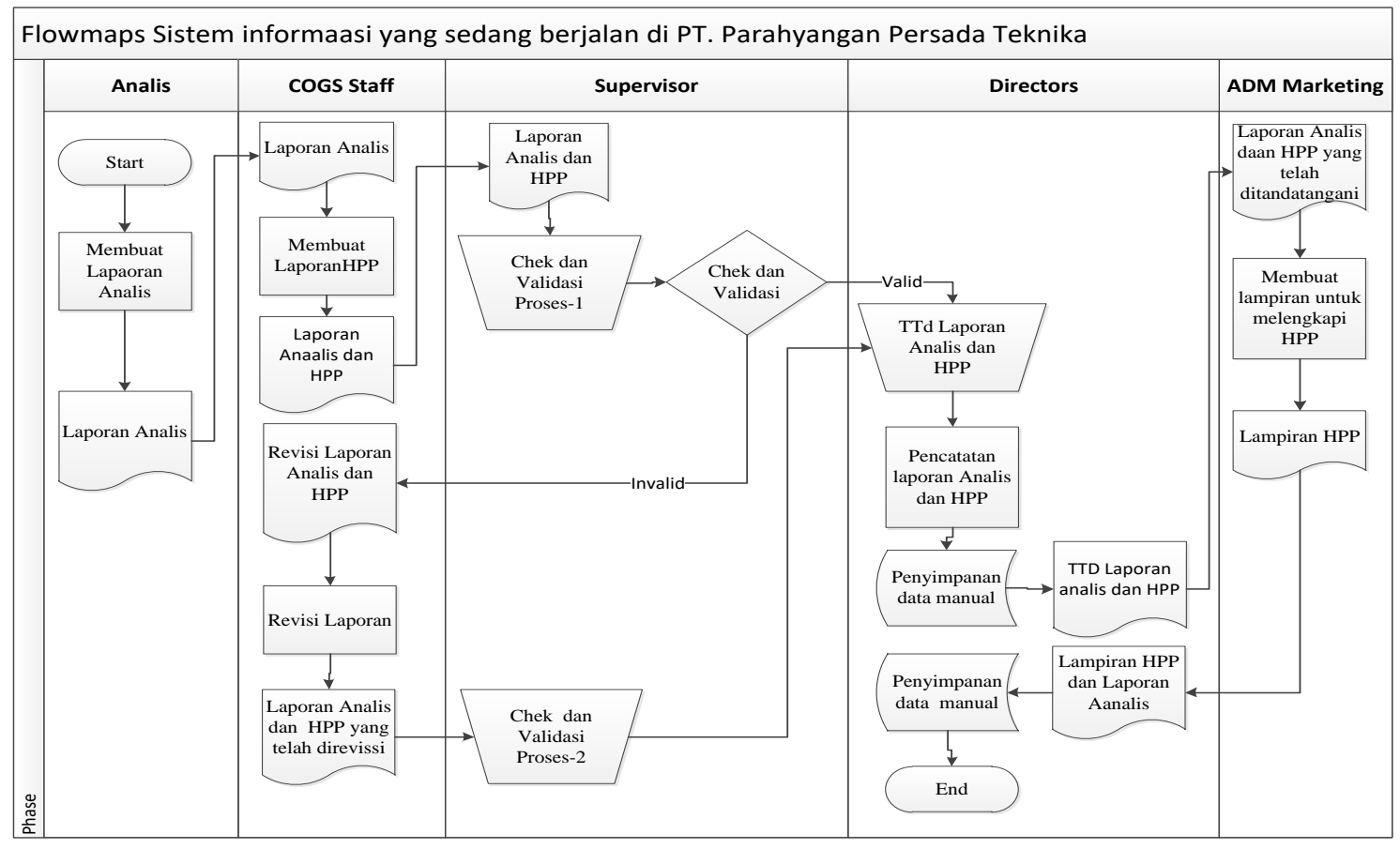

Gambar 2. Flowmap sistem informasi laporan kemajuan pekerjaan

di PT. Parahyangan Persada Teknika

\section{Evaluasi Sistem yang Ada}

Berdasarkan hasil observasi yang dilakukan peneliti, terdapat beberapa kelemahan pada sistem yang ada, seperti yang tertera pada tabel 1 dibawah ini:

\begin{tabular}{lll}
\hline No. & Permasalahan & Solusi \\
\hline & Sering mengalami kesulitan dalam pencarian laporan. & $\begin{array}{l}\text { Membuat database untuk memudahkan pencarian laporan yang } \\
\text { dibutuhkan. }\end{array}$ \\
\hline 1. & Terjadinyapenumpukan laporan. & $\begin{array}{l}\text { Membuat sistem kategori dan pengurutan untuk mengurangi } \\
\text { penumpukan laporan yang ada. }\end{array}$ \\
\hline 2. & $\begin{array}{l}\text { Membuat sistem pengkodean, waktu, dan penanggalan yang } \\
\text { yang sama. }\end{array}$ & $\begin{array}{l}\text { membantu mencegah terjadinya duplikasi laporan. } \\
\text { 3. }\end{array}$
\end{tabular}

Terdapat kendala terkait pelaksanaan prosedur protokol kesehatan
COVID-19, karena banyaknya interaksi langsung yang dilakukan teknologi jaringan ke sistem informasi.

\section{Perancangan Sistem}

Perancangan sistem informasi laporan kemajuan pekerjaan ini merupakan tindak lanjut dari analisis yang telah dilakukan pada bagian sebelumnya yang menjelaskan bagaimana suatu sistem dibentuk untuk menjadi solusi dari permasalahan yang terjadi, berdasarkan identifikasi dalam proses analisis dari sistem yang ada. Desain sistem menentukan bagaimana suatu sistem akan menyelesaikan apa yang perlu dilakukan. Tujuan dari desain sistem yang diusulkan adalah:

1. Untuk memenuhi sistem yang dibutuhkan.

2. Meningkatkan efektifitas dan efisiensi dalam penyimpanan laporan.

3. Minimalkan persentase kesalahan.

Perancangan fungsional sistem informasi ini diawali dengan berbagai tahapan dalam metode perancangan UML, yaitu sebagai berikut: 
JURSISTEKNI (Jurnal Sistem Informasi dan Teknologi Informasi) Vol 3, No.3, September 2021: Hal 9- 18

ISSN. P: 2715-1875, E: 2715-1883

1. Flowmap dari sistem informasi yang diusulkan

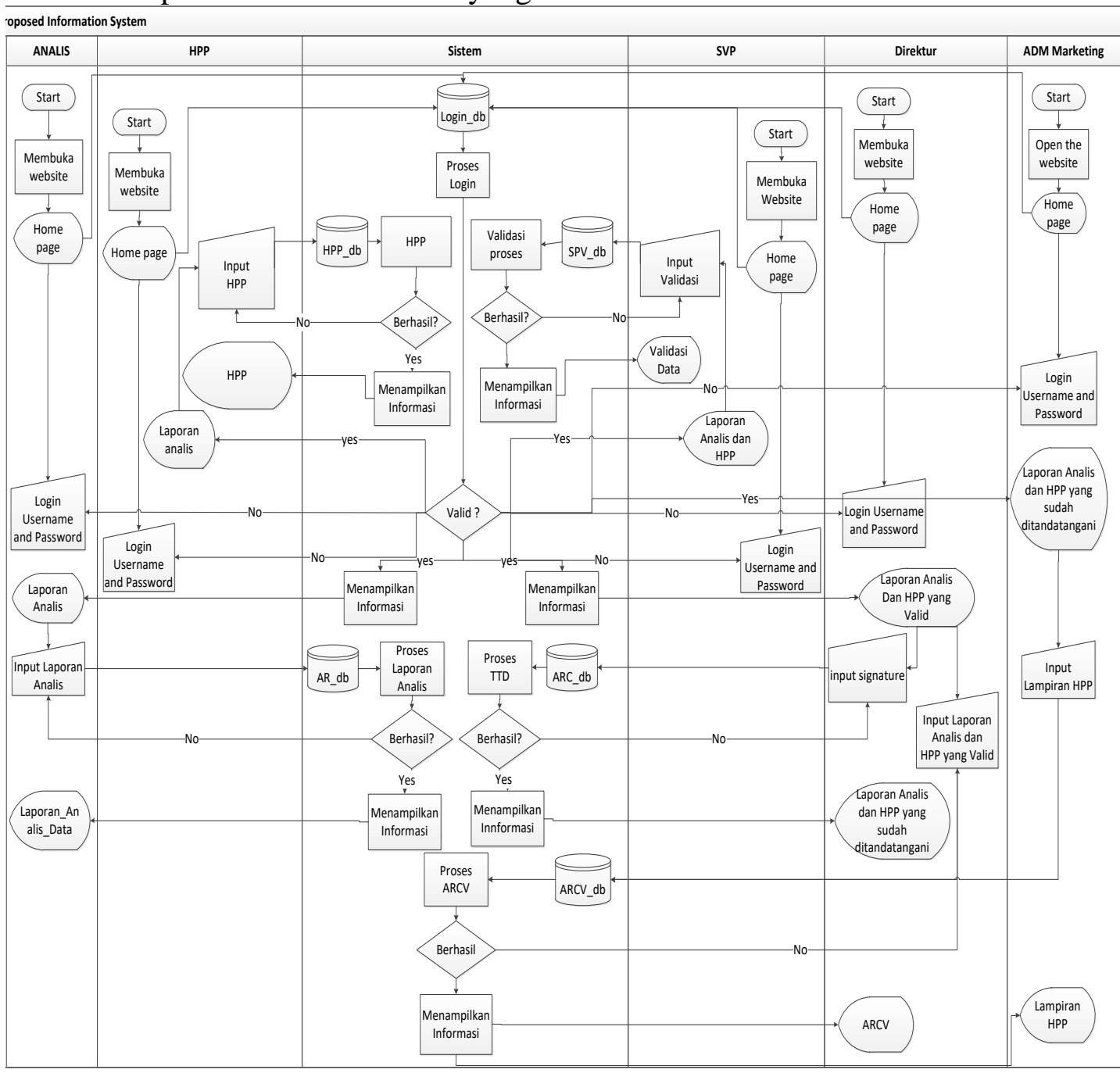

Gambar 3. Flowmap dari sistem informasi yang diusulkan

2. Diagram Konteks dari sistem yang diusulkan 
JURSISTEKNI (Jurnal Sistem Informasi dan Teknologi Informasi) Vol 3, No.3, September 2021: Hal 9- 18

ISSN. P: 2715-1875, E: 2715-1883

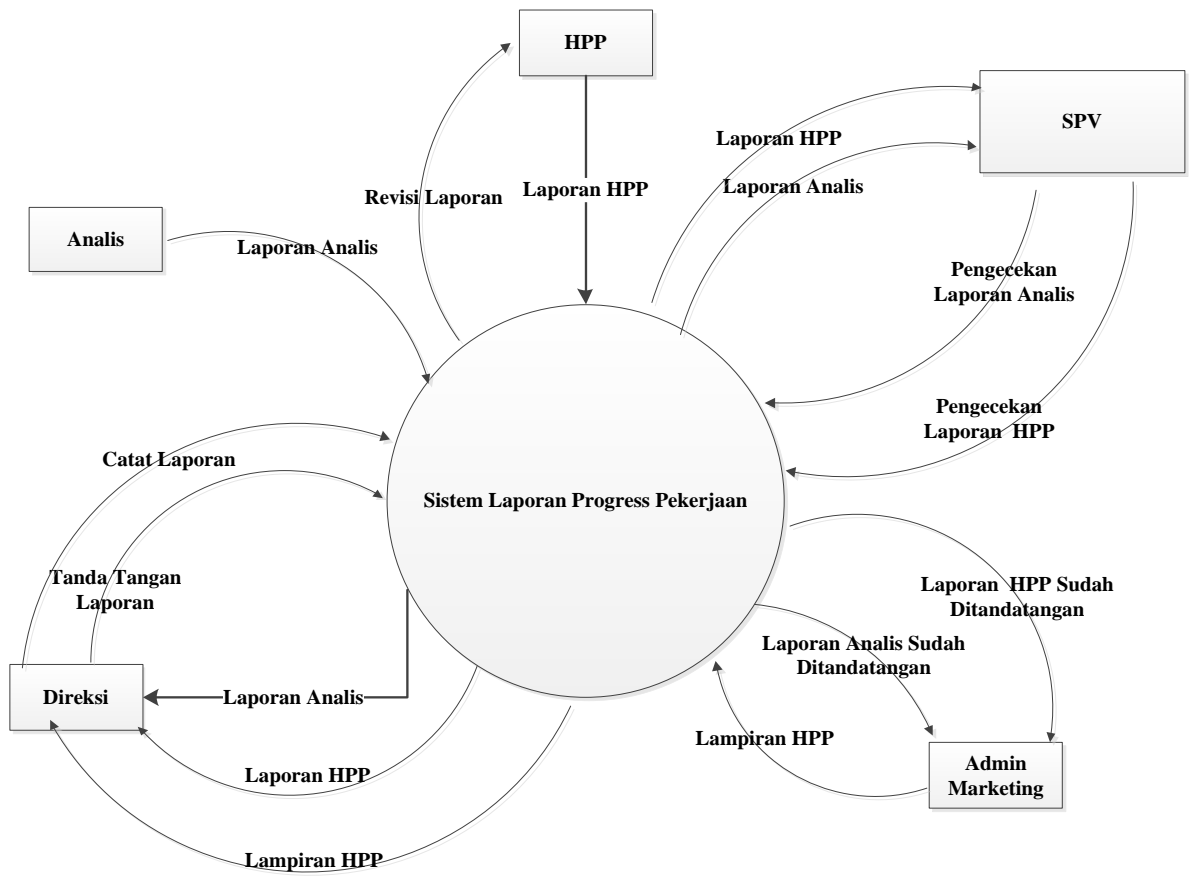

Gambar 4. Diagram Konteks Sistem yang Diusulkan

3. Data Flow Diagram dari sistem yang diusulkan

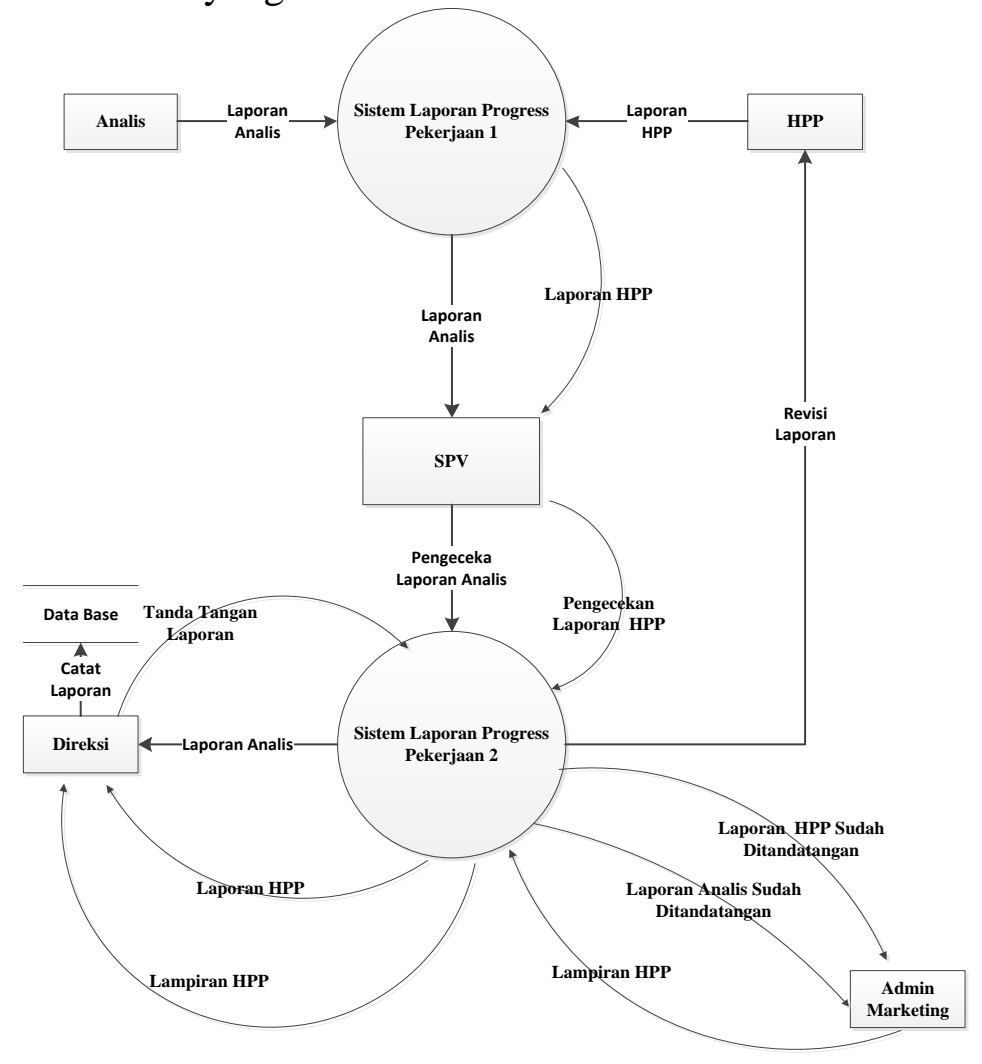

Gambar 5. Data Flow Diagram dari sistem yang diusulkan

4. Diagram Hubungan Entitas dari sistem yang diusulkan 
JURSISTEKNI (Jurnal Sistem Informasi dan Teknologi Informasi) Vol 3, No.3, September 2021: Hal 9- 18

ISSN. P: 2715-1875, E: 2715-1883

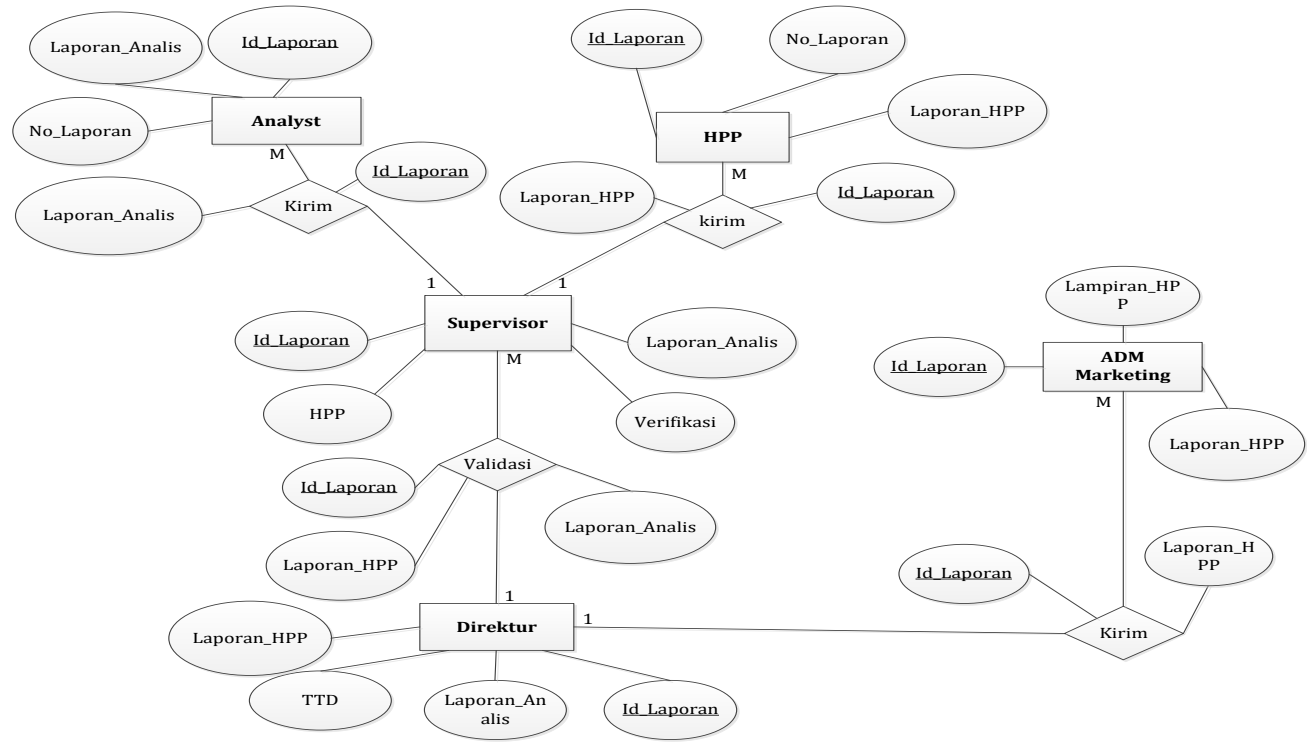

Gambar 6. Diagram Hubungan Entitas dari sistem yang diusulkan

\section{HASIL DAN PEMBAHASAN}

\section{A. Implementasi sistem}

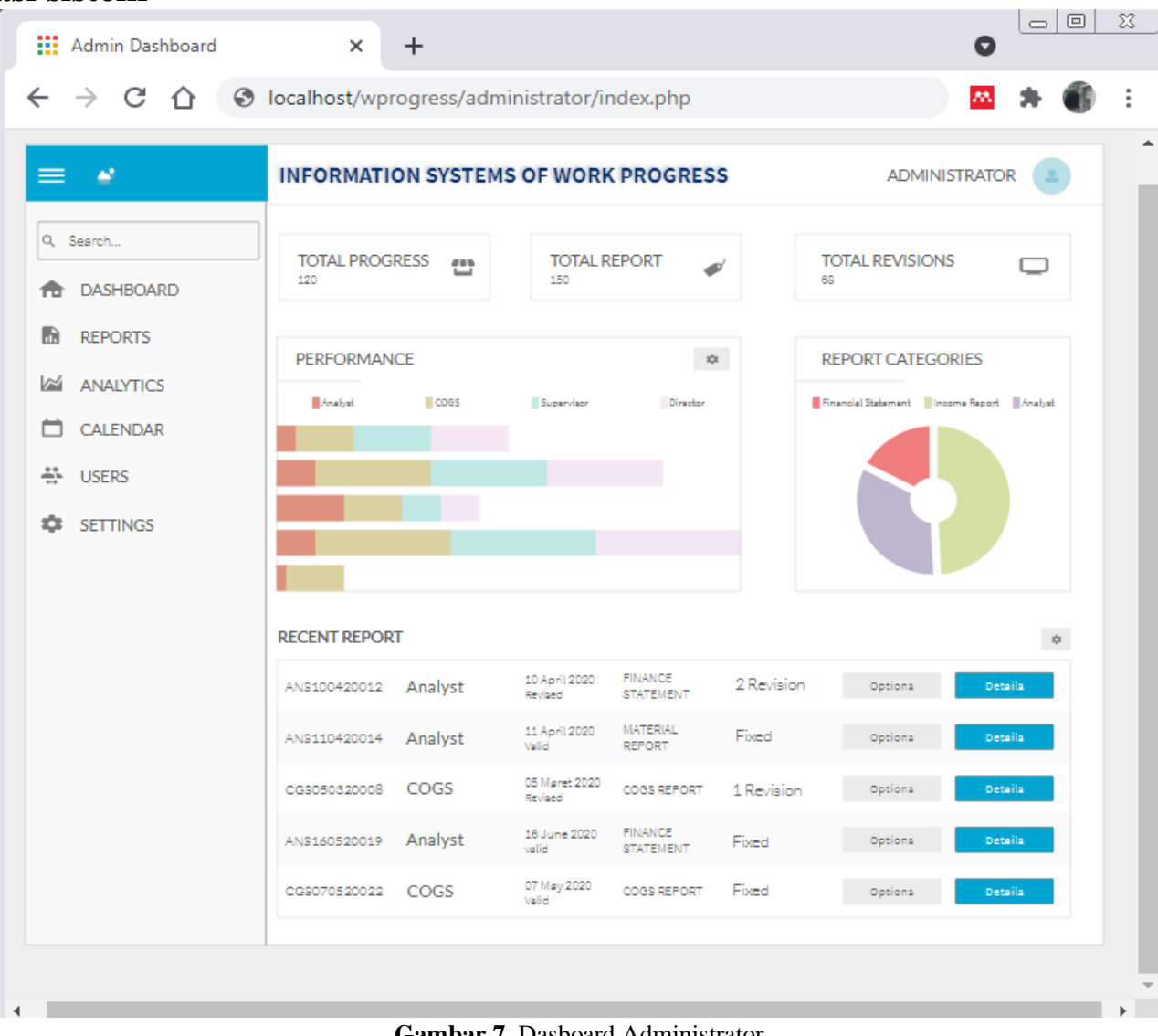

Gambar 7. Dasboard Administrator 


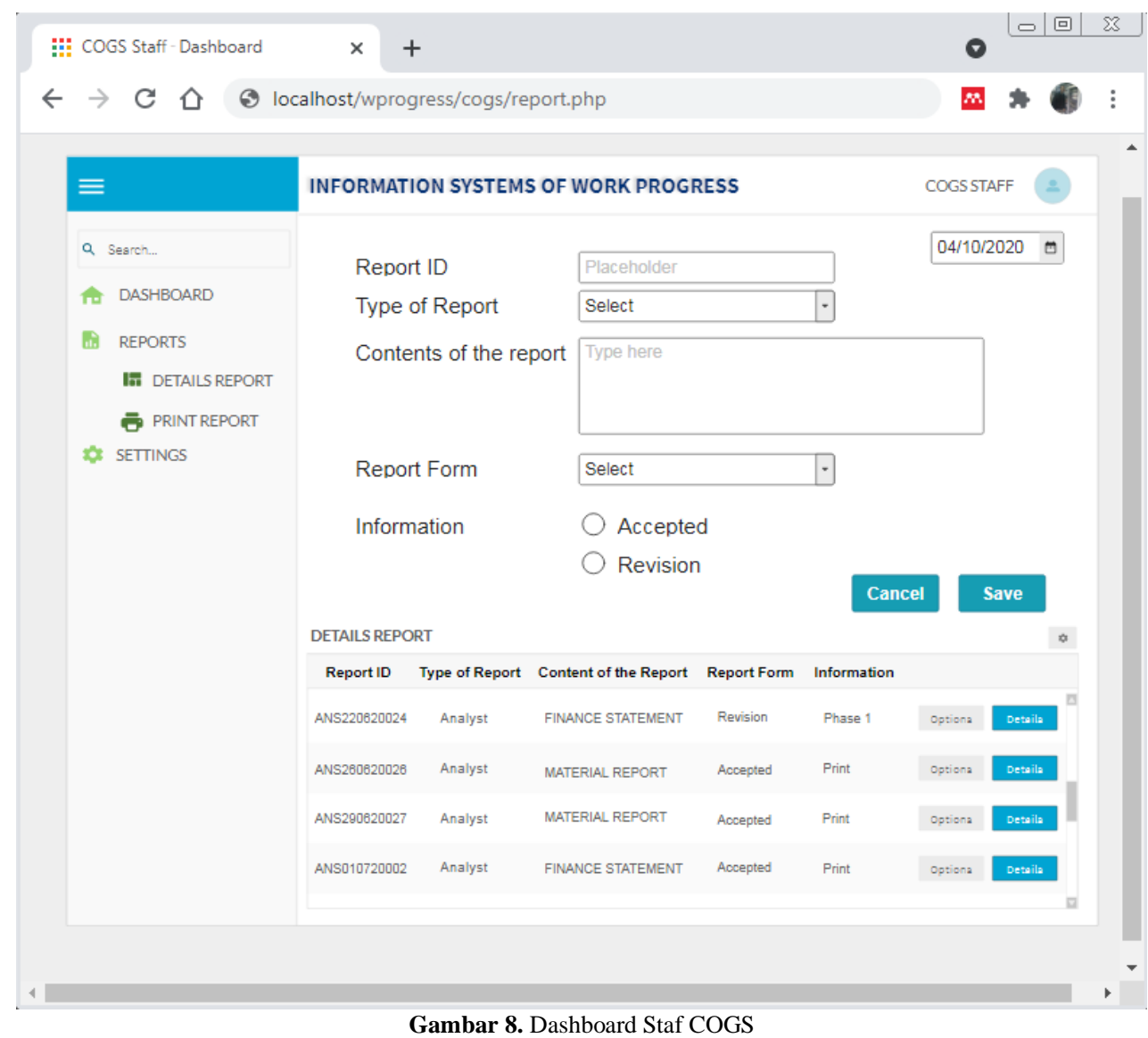

\section{B. Pengujian Sistem}

Pengujian perangkat lunak adalah kegiatan yang melibatkan beberapa kegiatan yang saling berhubungan antara satu dan yang lainnya [9]. Dimana yang menjadi sasaran utama dari kegiatan ini yaitu menjamin mutu produk[10].Berdasarkan pengujian dengan menggunakan metode blackbox bahwa keseluruhan fungsional sistem diantaranya adminitrator dan user dapat berfungsi dengan baik. Dan berdasarkan pengujian kegunaanmendapatkan presentase kelayakan sebesar96,64\% yang menunjukan bahwa sistem dapat diaplikasi pada . PT. Parahyanga Teknika Persada.

Tabel 2. Pengujian BlacBox

\begin{tabular}{|c|c|c|c|}
\hline \multicolumn{4}{|c|}{ Sistem : Administrator } \\
\hline No & Rancangan Proses & Hasil Yang Diharapkan & Hasil \\
\hline 1 & Isi username dan password, kemudian klik tombol Login & $\begin{array}{l}\text { Masuk ke halaman menu utama sebagai } a d m i n \text {, jika password salah } \\
\text { aka nada notifikasi }\end{array}$ & $\mathrm{OK}$ \\
\hline 2 & Klik tombol Logout & Keluar dari menu login & OK \\
\hline 3 & Ketik kode laporan lalu tekan enter & Laporan yang di maksud muncul atau terpanggil & OK \\
\hline 4 & Klik ACC Laporan Button & Data tersimpan dan tampil di dengan keterangan ACC Laporan & $\mathrm{OK}$ \\
\hline 5 & Klik tombol simpan & Laporan tersimpan di database & OK \\
\hline 6 & Klik Revisi Laporan Button & $\begin{array}{l}\text { Data tersimpan dan tampil di dengan keterangan Revisi Laporan dan } \\
\text { muncul kolom untuk diisi }\end{array}$ & OK \\
\hline 7 & Klik tombol Edit & Masuk ke menu edit dan bisa melakukan perubahan yang diinginkan & OK \\
\hline 8 & Klik tombol batal & Batal mengedit laporan & OK \\
\hline 9 & Klik tombol Tutup & Kembali ke menu utama login & OK \\
\hline 10 & Tanggal & Waktu berjalan secara otomatis untuk dijadikan kode laporan & OK \\
\hline \multirow[t]{2}{*}{11} & Klik tombol minimize & Halaman diperkecil & OK \\
\hline & Klik tombol close & Keluar dari aplikasi & OK \\
\hline
\end{tabular}

\begin{tabular}{cllc}
\hline Sistem : User & \multicolumn{1}{c}{ Rancangan Proses } & \multicolumn{1}{c}{ Hasil Yang Diharapkan } & Hasil \\
\hline No & \multicolumn{1}{c}{ OK } \\
\hline 1 & Isi username dan password, kemudian klik tombol Login & $\begin{array}{l}\text { Masuk ke halaman menu utama sebagai user, jika password salah aka } \\
\text { nada notifikasi }\end{array}$ & OK \\
\hline 2 & Klik tombol Logout & Keluar dari menu login & \\
\hline
\end{tabular}


JURSISTEKNI (Jurnal Sistem Informasi dan Teknologi Informasi) Vol 3, No.3, September 2021: Hal 9- 18 ISSN. P: 2715-1875, E: 2715-1883

\begin{tabular}{cll}
\hline 3 & Pilih Combo Box jenis laporan & Kode laporan muncul secara otomasi \\
\hline 4 & Pilih Combo Box bentuk laporan & Memunculkan pilihan data yang diperlukan \\
\hline 5 & Klik tombol simpan & Laporan tersimpan di table tbl_laporan \\
\hline 6 & Klik tombol Edit & Masuk ke menu edit dan bisa melakukan perubahan yang diinginkan \\
\hline 7 & Klik tombol batal & Batal mengedit laporan \\
\hline 8 & Klik tombol Tutup & Kembali ke menu utama login \\
\hline 9 & Tanggal & Waktu berjalan secara otomatis untuk dijadikan kode laporan \\
\hline 10 & Klik tombol minimize & OK \\
\hline 11 & Klik tombol close & OKaman diperkecil \\
\hline
\end{tabular}

1. Pengujian Kegunaan (Usability)

Untuk pengujian kegunaan, dilakukan kepada pengguna, dan tanpa kehadiran pihak pembuat aplikasi dibutuhkan kuesioner yang harus diisi guna mengetahui apakah atau seberapa baikkah aplikasi desktop yang dibuat. Kuesioner terdiri dari lima pertanyaan yang ditujukan kepada dua puluh lima responden. Responden akan menjawab lima pertanyaan yang diberikan terkait dengan program yang telah dibuat.

Kuesioner menggunakan menggunakan skala likert 1 (satu) sampai 5 (lima). Berikut ini adalah detail skala likert yang dapat dilihat pada tabel 3.

Tabel 3. Penskoran Jawaban

\begin{tabular}{lc} 
Jawaban & Skor \\
\hline $\mathrm{SP}=$ Sangat Puas & 5 \\
\hline $\mathrm{CP}=$ Cukup Puas & 4 \\
\hline $\mathrm{P}=$ Puas & 3 \\
\hline $\mathrm{KP}=$ Kurang Puas & 2 \\
\hline $\mathrm{TP}=$ Tidak Puas & 1 \\
\hline \multicolumn{2}{c}{ Sumber : Diolah oleh penulis $(2020)$}
\end{tabular}

Tabel 4. Tabulasi Data Jawaban Responden

Pertanyaan SP CP

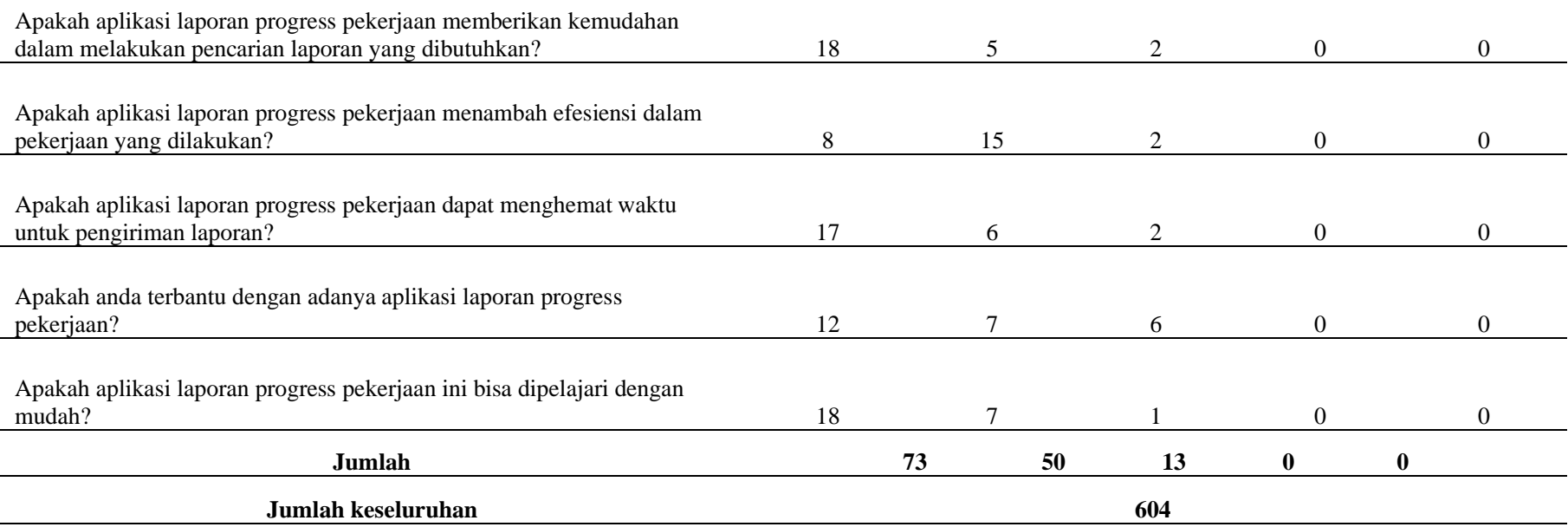

Jumlah Keseluruhan $=(73 \times 5)+(50 \times 4)+(13 \times 3)+(0 \times 2)+(0 \times 1)$

Jumlah Keseluruhan $=604$

Presentase kelayakan dapat dihitung dengan rumus berikut. Presentase kelayakan (Y )= jumlah keseluruhan (P) / jumlah skor yang diharapkan (Q) x 100

Presentase kelayakan $=604 / 625 \times 100=96,64 \%$, dimana dalam skala likert berada pada rentang 80$100 \%$ yang termasuk dalam kategori sangat puas.

\section{KESIMPULAN}

Dari hasil penelitian dapat disimpulkan bahwa sistem informasi laporan kemajuan pekerjaan dapat mempermudah pemilihan laporan yang sudah selesai, dan juga membantu karyawan PT. Parahyangan 
Teknika Persada dalam mengevaluasi laporan yang dibuatnya. Selain itu, dengan sistem informasi laporan kemajuan kerja berbasis jaringan, kepatuhan terhadap disiplin protokol kesehatan dapat terjaga dan tidak ada lagi penumpukan laporan sejenis yang dapat menurunkan efektivitas pelaporan.

\section{DAFTAR PUSTAKA}

[1] J. Lieponienè, "Recent Trends in Database Technology," Balt. J. Mod. Comput., vol. 8, no. 4, 2020, doi: 10.22364/bjmc.2020.8.4.06.

[2] A. Van Os, F. Van Berkel, D. De Gilder, C. Van Dyck, and P. Groenewegen, "Project risk as identity threat: Explaining the development and consequences of risk discourse in an infrastructure project," Int. J. Proj. Manag., vol. 33, no. 4, 2015, doi: 10.1016/j.ijproman.2014.10.016.

[3] S. Bay et al., "Appendix d adaptive management plan," 2007.

[4] M. T. Drs. Agus Suryanto and S. T. M. E. Anan Nugroho, Manajemen Proyek Teknologi Informasi, 1st ed. Yogyakarta: Deepublish, 2020.

[5] G. Sotgiu and C. C. Dobler, "Social stigma in the time of coronavirus disease 2019," Eur. Respir. J., vol. 56, no. 2, p. 2002461, Aug. 2020, doi: 10.1183/13993003.02461-2020.

[6] A. Andriyani, M. Sihite, and E. Supriyadi, "PERAN STAKEHOLDER, PROJECT PERFORMANCE, KEBIJAKAN PEMERINTAH PADA PSN BANDARA AHMAD YANI SEMARANG," J. EKOBISMAN, vol. 5, no. 1, pp. 53-70, 2020, doi: https://doi.org/10.35814/jeko.v5i1.1644.

[7] Mutakallim, "Pengawasan, Evaluasi dan Umpan Balik Stratejik," Vol. V, Nomor 2, vol. V, no. JuliDesember 2016, pp. 351-365, 2016, [Online]. Available: http://nurinaramadhani.blogspot.com/2012/01/pengawasan-pengawasan-\%0Ahttp://journal.uinalauddin.ac.id/index.php/Inspiratif-Pendidikan/article/download/3489/3273.

[8] I. P. D. Lesmana and E. Antika, MANAJEMEN PROYEK DENGAN SCRUM, 1st ed. Yogyakarta: Absolute Media, 2020.

[9] M. S. Mustaqbal, R. F. Firdaus, and H. Rahmadi, "PENGUJIAN APLIKASI MENGGUNAKAN BLACK BOX TESTING BOUNDARY VALUE ANALYSIS (STUDI KASUS : APLIKASI PREDIKSI KELULUSAN SMNPTN)," 2015.

[10] H. Sulistyanto and A. SN, "Urgensi Pengujian pada Kemajemukan Perangkat Lunak dalam Multi Perspektif," KomuniTi, vol. 6, no. 1, pp. 65-74, 2014, doi: https://doi.org/10.23917/komuniti.v6i1.2944. 